\title{
Research
}

\section{TCOs for Nip Thin Film Silicon Solar Cells}

T. Söderström ${ }^{* \dagger \dagger}$, F.-J. Haug, X. Niquille and C. Ballif

Institute of Microtechnology, University of Neuchâtel, Rue A.-L. Breguet 2, CH-2000 Neuchâtel, Switzerland

Substrate configuration allows for the deposition of thin film silicon (Si) solar cells on non-transparent substrates such as plastic sheets or metallic foils. In this work, we develop processes compatible with low $T_{g}$ plastics. The amorphous Si (a-Si:H) and microcrystalline Si ( $\mu$ c-Si:H) films are deposited by plasma enhanced chemical vapour deposition, at very high excitation frequencies (VHF-PECVD). We investigate the optical behaviour of single and triple junction devices prepared with different back and front contacts. The back contact consists either of a 2D periodic grid with moderate slope, or of low pressure CVD (LP-CVD) $\mathrm{ZnO}$ with random pyramids of various sizes. The front contacts are either a $70 \mathrm{~nm}$ thick, nominally flat ITO or a rough $2 \mu \mathrm{m}$ thick $\mathrm{LP}-\mathrm{CVD} \mathrm{ZnO}$. We observe that, for a-Si:H, the cell performance depends critically on the combination of thin flat or thick rough front TCOs and the back contact. Indeed, for a-Si:H, a thick LP-CVD $\mathrm{ZnO}$ front contact provides more light trapping on the $2 \mathrm{D}$ periodic substrate. Then, we investigate the influence of the thick and thin TCOs in conjunction with thick absorbers ( $\mu$ c-Si:H). Because of the different nature of the optical systems (thick against thin absorber layer), the antireflection effect of ITO becomes more effective and the structure with the flat TCO provides as much light trapping as the rough LP-CVD ZnO. Finally, the conformality of the layers is investigated and guidelines are given to understand the effectiveness of the light trapping in devices deposited on periodic gratings. Copyright (C) 2008 John Wiley \& Sons, Ltd.

KEY WORDS: TCO; light trapping; thin film silicon; amorphous; microcrystalline; solar cells

Received 1 July 2008; Revised 2 October 2008

\section{INTRODUCTION}

The industrialisation of silicon ( $\mathrm{Si}$ ) thin film solar cells started 30 years ago with the film deposition of amorphous silicon (a-Si:H) by glow discharge of silane gas $\left(\mathrm{SiH}_{4}\right),{ }^{1}$ resulting in the introduction of these cells into pocket calculators. Today, mass production has started with over $3 \mathrm{GW}$ announced annual solar module production capacity by $2010^{2}$ which will represent 40 million square meters (assuming modules at $7.5 \%$

* Correspondence to: T. Söderström, Institute of Microtechnology, University of Neuchâtel, Rue A.-L. Breguet 2, CH-2000 Neuchâtel, Switzerland.

${ }^{\dagger}$ E-mail: thomas.soderstrom@unine.ch efficiency). In this market, the substrate or nip configuration offers a competitive advantage because flexible, light weight, non-transparent substrates can be used more effectively, ${ }^{3}$ and roll to roll deposition techniques can be applied. ${ }^{4}$

In this work, we develop low temperature processes (below $200^{\circ} \mathrm{C}$ ) compatible with low cost plastic substrates such as polyethylene-naphtalate (PEN) or polyethylene-terephtalate (PET). Our current primary goal is to increase the stabilised efficiency of thin film silicon solar cells; a-Si-H, microcrystalline ( $\mu \mathrm{c}-\mathrm{Si}: \mathrm{H})$, tandem micromorph (stack of a-Si:H and $\mu \mathrm{c}-\mathrm{Si}: \mathrm{H}$ solar cells) ${ }^{5}$ and multijunction structures in the nip substrate configuration. ${ }^{6}$ The first challenge is to increase the 
short circuit current density $\left(J_{\mathrm{sc}}\right)$ by introducing light trapping techniques in the thin film silicon solar cells. Hence, the cell thickness can be reduced which leads to reduction of the light-induced degradation effects for a-Si:H material ${ }^{7}$ and more effective cycle times in production for both a-Si:H and $\mu \mathrm{c}-\mathrm{Si}: \mathrm{H}$ solar cells. Light trapping in the absorber is often achieved by introducing textured interfaces which cause light scattering. And for efficient light scattering, the substrate textures should be in the dimension range of the incoming light wavelength. The strategy used in the superstrate or pin configuration is to deposit a rough front transparent conductive oxide (TCO) on glass with random $^{8}$ or periodic ${ }^{9}$ structures which scatter the light in the absorber layer and increase the path of the light in the absorber material. State-of-theart light trapping designs are produced by the company Kaneka, ${ }^{10}$ the research centre of Jülich ${ }^{11,12}$ and research laboratory of Neuchâtel. ${ }^{13,14}$ They use random structures and typical values of $J_{\mathrm{sc}}$ are $15 \mathrm{~mA} / \mathrm{cm}^{2}$ for $180 \mathrm{~nm}$ a-Si:H absorber and $26 \mathrm{~mA} /$ $\mathrm{cm}^{2}$ for $3 \mu \mathrm{m} \mu \mathrm{c}-\mathrm{Si}: \mathrm{H}$ absorber as describe by Dominé et al. ${ }^{14,15}$ In the nip configuration, the strategy relies on the substrate texture which creates roughness (textured interfaces) in the next deposited layers, and deposition of a thin $70 \mathrm{~nm}$ ITO front contact which acts as an antireflection layer as reported by United Solar. ${ }^{3,16}$ Nevertheless, the optimum morphology of the back texture is still unknown and it is not yet confirmed whether the best substrate should have a periodic or random structure. Also, there is a trade off between the suitable texture for the light scattering and the losses in the back reflector which come from surface plasmon absorptions in the rough metallic layer. ${ }^{17,18}$ Strong efforts are being made in optical modelling with the aim of predicting the light trapping power of optical designs. Given the size of typical light trapping structures, the optical system is at the frontier between geometrical and nanooptics, and usually for modelling of the random structures semi-empirical theories are applied such as 'scalar scattering theory'. ${ }^{19}$ This approach has been implemented in different simulation programs, e.g. by Krc et al., ${ }^{20}$ Zeman et al. ${ }^{21}$ and Springer et al. ${ }^{22}$ Another approach is to use periodic structures where exact solutions of Maxwell's equations have been performed by Heine and Morf. ${ }^{23}$ In addition, numerical solutions of Maxwell's equations have been performed with success by Stiebig and Haase. ${ }^{24,25}$ However, typical devices with roughness structures and thicknesses of the layers in the range of the incoming light wavelength are still difficult to analyse either because of oversimplified assumptions or because of difficulties in performing exact numerical simulations for complex systems. Thus, the predictive power of these models remains limited and experimental data are crucial to improve both models and devices.

Our experimental investigations address the interaction between back contact structures and front contacts TCO, including the effect of the film silicon absorber layer that is sandwiched between the two. We compare two TCOs as front contacts; the first one is a flat thin $(70 \mathrm{~nm})$ ITO layer and the second is a rough thick (over $2 \mu \mathrm{m}$ ) $\mathrm{ZnO}$ deposited by low pressure chemical vapour deposition (LP-CVD). The TCOs are applied to various devices and substrate structures: in particular we consider the case of thin a-Si:H and thick $\mu \mathrm{c}-\mathrm{Si} \mathrm{H}$ devices deposited on random and periodic substrates. A priori, it is expected that the roughness created by an LP-CVD ZnO front contact could scatter the incoming light and thus could participate in the light trapping scheme of the solar cells. Our results show that this air/TCO scattering effect does play an important part but it reveals that the thickness of the LP-CVD ZnO layer can be an important property, depending on the substrate's texture. In addition, we find that the optimum dimension of the substrate texture is different for the two types of cell, not only because the light trapping region is increased towards the near infra-red (IR) part of the spectrum for the $\mu \mathrm{c}-\mathrm{Si}: \mathrm{H}$, but also because the optical couplings in a system with thin a-Si:H $(250 \mathrm{~nm})$ absorber and a thick $(1-2 \mu \mathrm{m}) \mu \mathrm{c}-\mathrm{Si}: \mathrm{H}$ absorber are completely different. Thus, the combination of front contacts and substrate structures is studied and interpreted for a-Si:H and $\mu \mathrm{c}-\mathrm{Si}: \mathrm{H}$ solar cells.

\section{EXPERIMENTAL}

Two substrates are considered in this paper. The first structure is a 2D periodic grating on PEN covered with $100 \mathrm{~nm}$ silver $(\mathrm{Ag})$ and $60 \mathrm{~nm} \mathrm{ZnO}$, as described by Haug et $\mathrm{al}^{26}$ which is well suited for $\mu \mathrm{c}-\mathrm{Si}: \mathrm{H}$, micromorph or triple a-Si:H/a-Si:H/ $\mu \mathrm{c}-\mathrm{Si}: \mathrm{H}$ solar cells. This structure has a root mean square (RMS) roughness of $70 \mathrm{~nm}$ and lateral dimension of $1.2 \mu \mathrm{m}$ (Figure 1A and B). The second structure consists of a random pyramidal structure that develops in LP-CVD $\mathrm{ZnO}$ growth and which provides high $J_{\mathrm{sc}}$ for single a-Si:H junction solar cells (Figure $1 \mathrm{C}$ and D). The feature size of the LP-CVD ZnO can also be adapted for the light trapping in $\mu \mathrm{c}-\mathrm{Si}: \mathrm{H}$ or multiple-junction 


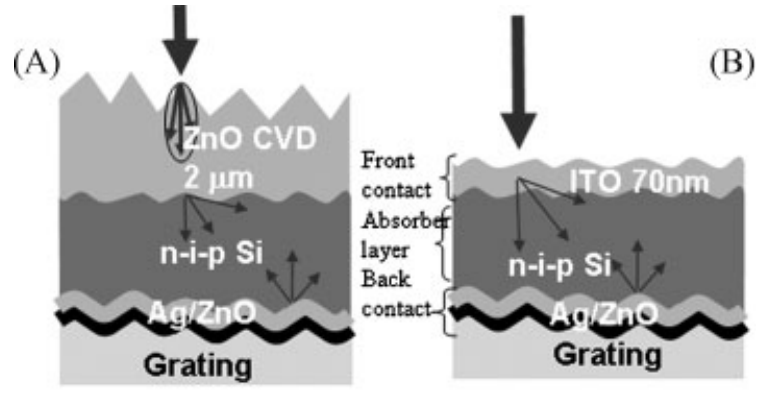

(C)

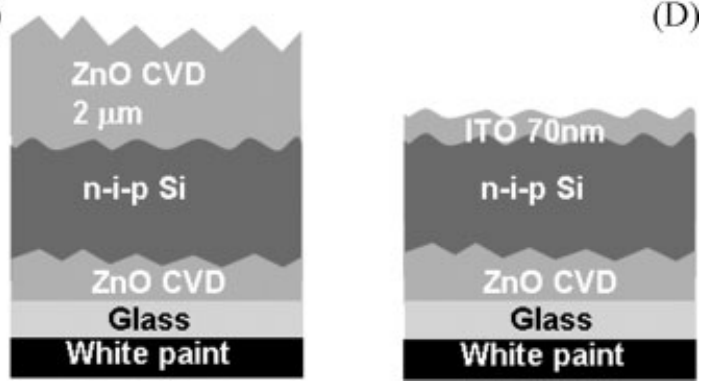

Figure 1. Schematic illustration of the four different designs used in this paper. Two substrates and two front contacts are used in a-Si $\mathrm{H}$ and $\mu \mathrm{c}-\mathrm{Si}: \mathrm{H}$ solar cells. A and B are plastic substrates with a $2 \mathrm{D}$ crossgrating covered with $100 \mathrm{~nm}$ of silver and $60 \mathrm{~nm}$ sputtered $\mathrm{ZnO}$. $\mathrm{C}$ and $\mathrm{D}$ are glass substrates covered with a rough $\mathrm{LP}-\mathrm{CVD} \mathrm{ZnO}$ and white paint is used as a back reflector. A thin $70 \mathrm{~nm}$ ITO front contact is used for B and $\mathrm{D}$ and $2 \mu \mathrm{m}$ thick LP-CVD ZnO for A and C

cells by increasing the grain size. When adapted for $\mu \mathrm{c}-\mathrm{Si}: \mathrm{H}$ or multiple-junction cells, the morphology of the LP-CVD $\mathrm{ZnO}$ has to be changed from V shape valleys to $U$ shape valleys by a surface plasma treatment in order to maintain good electrical properties of the $\mu \mathrm{c}-\mathrm{Si}: \mathrm{H}$ solar cells. Further details on the effect of the plasma treatment is described for a-Si: $\mathrm{H}^{27}$ and $\mu \mathrm{c}-\mathrm{Si}: \mathrm{H}^{28-30}$ In this work, typical RMS and lateral dimension are 70 and $360 \mathrm{~nm}$ for a-Si:H solar cells and $140 \mathrm{~nm}$ and $1 \mu \mathrm{m}$ for $\mu \mathrm{c}-\mathrm{Si}: \mathrm{H}$ solar cells, respectively. The surface plasma treatment time is short for a-Si:H and does not significantly modify the LP-CVD ZnO morphologies. For the $\mu \mathrm{c}-\mathrm{Si}: \mathrm{H}$ case, increased treatment time improves dramatically the open circuit voltage $\left(V_{\mathrm{oc}}\right)$ and fill factor $(\mathrm{FF})$ of the solar cells. Hence for comparison with the periodic substrates, we choose a treatment time on which the $\mu \mathrm{c}-\mathrm{Si}: \mathrm{H}$ solar cell on LP-CVD ZnO has $V_{\mathrm{oc}}$ and FF equal to the $V_{\mathrm{oc}}$ and FF of the periodic substrate. The back reflector on the glass substrate is a white paint (Tipp-Ex) applied at the back of the $0.7 \mathrm{~mm}$ glass (Schott AF45).
The silicon films are deposited by plasma enhanced CVD, at very high excitation frequencies (VHFPECVD, $70 \mathrm{MHz})$. The main gases for the deposition are silane $\left(\mathrm{SiH}_{4}\right)$, hydrogen $\left(\mathrm{H}_{2}\right)$, and methane $\left(\mathrm{CH}_{4}\right)$. Phosphine $\left(\mathrm{PH}_{3}\right)$ and trimethylboron (TMB) are added for the $\mathrm{n}$ and $\mathrm{p}$ doped layers, respectively.

The transparent front electrodes are $\mathrm{ZnO}$ deposited by LP-CVD $\mathrm{ZnO}^{31}$ (Figure 1A and C) or indium tin oxide (ITO) deposited by DC sputtering at room temperature (Figure $1 \mathrm{~B}$ and $\mathrm{D}$ ). The $\mathrm{ZnO}$ is doped with boron and its deposition conditions result in a textured surface with RMS roughness of about $70 \mathrm{~nm}$ for $2 \mu \mathrm{m}$ thick layers. The ITO is deposited nominally flat, and it has a thickness of $70 \mathrm{~nm}$ in order to achieve an antireflection condition between air and $\mathrm{Si}$. The total transmission $(T)$, diffuse transmission (DT), and total reflexion $(R)$ are measured with a photo-spectrometer (Perkin Elmer lambda 900) with integration-sphere within a spectral range of $350-2000 \mathrm{~nm}$. The absorbance $(A)$ is calculated from $T$ and $R$ with $A=1-T-R$. The measured samples are $\mathrm{TCO} /$ glass with the light first entering through the TCO. For the rough $\mathrm{ZnO}$, the measurement is also performed with a thin film of index matching liquid diiodomethane $\left(\mathrm{CH}_{2} \mathrm{I}_{2}\right)$. It switches off the effect of rough interfaces during transmission and reflectance measurements as described by Steinhauser et al. ${ }^{32}$

The external quantum efficiency (EQE) is measured with a spectral response setup and the internal quantum efficiency (IQE) is calculated as IQE $=\frac{\mathrm{EQE}}{1-R}$. The EQE curve is given at short circuit condition except when something else is specified. The short circuit current density $\left(J_{\mathrm{sc}}\right)$ is calculated from the EQE by convolution with the AM $1.5 \mathrm{~g}$ solar spectrum and integration over the wavelength range. The current density-voltage $(J V)$ measurements are performed with a class A AM $1.5 \mathrm{~g}$ sun simulator at standard conditions (Wacom, $25^{\circ} \mathrm{C}, 100 \mathrm{~mW} / \mathrm{cm}^{2}$ ). From that $\mathrm{JV}$ curve the $V_{\mathrm{oc}}$ and FF are obtained and current densities are normalised with the $J_{\mathrm{sc}}$ value obtained from the EQE measurement. This method avoids uncertainties in the determination of the solar cell surface area.

\section{RESULTS}

\section{Thick textured LP-CVD ZnO and flat ITO on glass}

In Figure 2, it shows T, R and A curves of the ITO and LP-CVD ZnO with $\mathrm{CH}_{2} \mathrm{I}_{2}$ on glass. The absorbance of the $\mathrm{ZnO}$ with $\mathrm{CH}_{2} \mathrm{I}_{2}$ and ITO is equivalent and below $3 \%$ overall the wavelengths between 400 and $1100 \mathrm{~nm}$. The difference in $T$ and $R$ is due to the different optical 


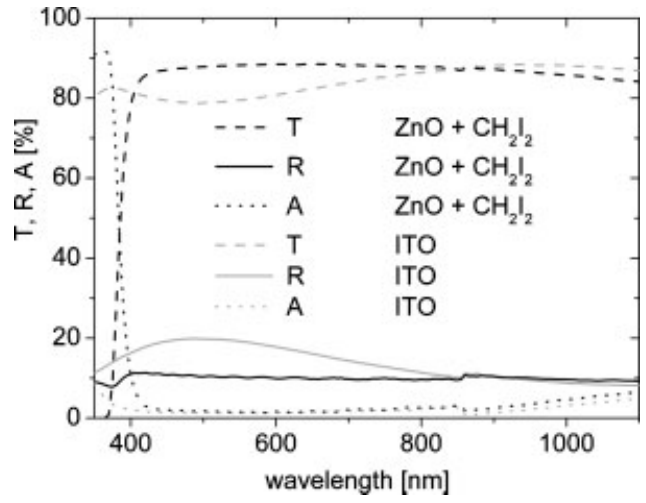

Figure 2. T, R and A of a flat $80 \mathrm{~nm}$ ITO on glass, $2 \mu \mathrm{m}$ thick ZnO LP-CVD on glass measured with $\mathrm{CH}_{2} \mathrm{I}_{2}$ index matching liquid

thickness of the systems: $2 \mu \mathrm{m}$ thick $\mathrm{ZnO}$ and thin $80 \mathrm{~nm}$ ITO films. Hence in Figure 2, interference appears for the thin flat ITO. Figure 3 shows that, when no matching liquid and cover glass is used, the textured $\mathrm{ZnO}$ provides diffuse transmittance, which is negligible in the case of ITO and of $\mathrm{ZnO}$ measured with $\mathrm{CH}_{2} \mathrm{I}_{2}$. The rough interface of the $\mathrm{ZnO}$ leads to an increase in the absorbance between 400 and $1000 \mathrm{~nm}$ and reflection between 400 and $700 \mathrm{~nm}$ as shown in Figure 3. Enhanced absorption is attributed to light trapping in the $2 \mu \mathrm{m}$ thick $\mathrm{ZnO}$ due to scattering of the light at the air/ZnO interface and internal reflection between the glass/air and the $\mathrm{ZnO} /$ air interfaces. It enhances the path of the light in the $\mathrm{ZnO}$ and increases absorption due to residual optical defects and freecarrier absorption, whereas the reflectance is increased because incident angle of the light on the flat $\mathrm{ZnO}$ /

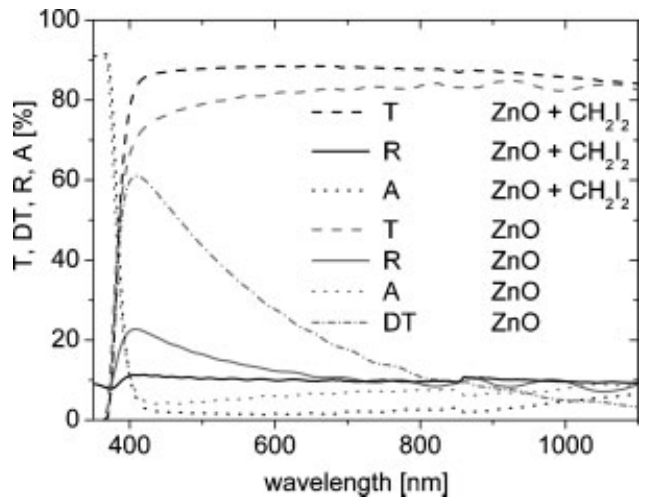

Figure 3. T, TD, $\mathrm{R}$ and $\mathrm{A}$ for $2 \mu \mathrm{m}$ rough $\mathrm{ZnO}$ LP-CVD layer and for $\mathrm{ZnO} \mathrm{LP}-\mathrm{CVD}$ with $\mathrm{CH}_{2} \mathrm{I}_{2}$ glass interface is increased. This TCO/glass structure does not give direct information on the optical behaviour in the solar cell $(\mathrm{TCO} / \mathrm{Si})$ because light trapping due to total internal reflection (TIR) will not take place for the TCO/Si interface $\left(\mathrm{n}_{\mathrm{Si}}>\mathrm{n}_{\mathrm{TCO}}\right.$, which is different from $\mathrm{n}_{\mathrm{TCO}}>$ nglass at the $\mathrm{TCO} /$ glass interface). Nevertheless, it can provide useful data to calibrate models and simulations software based on exact and semi-empirical theories. Note, that the Haze (DT/T) of the textured $\mathrm{ZnO}$ is $85 \%$ at $400 \mathrm{~nm}$ and only $12 \%$ at $800 \mathrm{~nm}$. Hence, the scattering power our textured $\mathrm{ZnO}$ is, in air, limited for the IR part of the spectrum which is crucial for elevated light trapping in thin film silicon solar cells.

\section{LP-CVD ZnO and ITO front contacts for thin} absorber (a-Si:H)

In Figure 4, we compare the EQE of a-Si:H solar cells with $270 \mathrm{~nm}$ thick absorber layer and two different front TCOs (rough thick front LP-CVD $\mathrm{ZnO}$ and thin flat ITO) deposited on flat substrates for reference and on the $2 \mathrm{D}$ periodic substrate ( $70 \mathrm{~nm}$ RMS). The $J_{\mathrm{sc}}$ on flat substrates for both fronts TCO is almost identical with 12.2 and $12.3 \mathrm{~mA} / \mathrm{cm}^{2}$ for ITO and $\mathrm{ZnO}$, respectively. However, the EQE of the cell with $\mathrm{ZnO}$ is higher at wavelength above $600 \mathrm{~nm}$ whereas the EQE with ITO is higher between 450 and $550 \mathrm{~nm}$ thanks its antireflection effect with silicon. We think that the roughness of the front $\mathrm{ZnO}$ provides the moderate increase in absorption in the IR. Hence, on flat substrates the LP-CVD $\mathrm{ZnO}$ front contact is as good as the traditional ITO front contact for the $J_{\text {sc }}$. On the periodically textured substrate, we observe a $J_{\mathrm{sc}}$

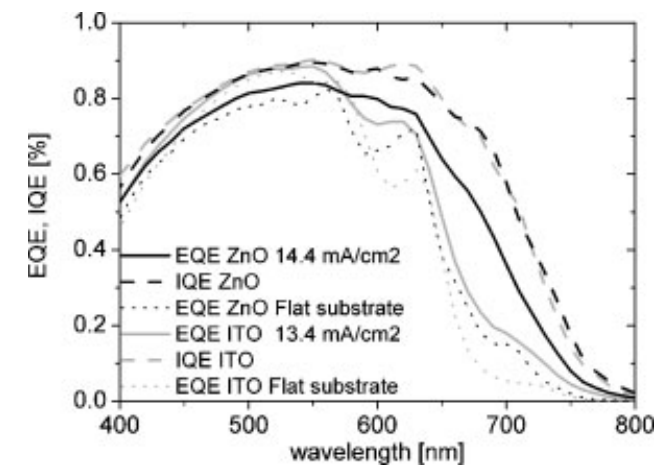

Figure 4. Comparison between flat ITO and rough LP-CVD

$\mathrm{ZnO}$ front contacts with a-Si:H solar cells deposited on a $2 \mathrm{D}$ grid substrate and flat substrates for reference 
enhancement of $9 \%$ with ITO and $17 \%$ with LP-CVD $\mathrm{ZnO}$, compared to the flat substrate. Compared to thin ITO front contact, the enhancement with the textured $\mathrm{ZnO}$ front contact is mostly obtained for the IR part of the spectrum as shown in Figure 4. The IQEs are equals, indicating identical properties of the absorber layer and no additional absorption effects in the inactive device layers. Hence, the LP-CVD ZnO yields true enhancement of light trapping in the IR compared to the thin flat ITO. The reason for this strong enhancement is mostly attributed to the thickness of the TCO layer and not due to the roughness of the front interface, as discussed in Section 'Discussion'.

In Figure 5, we compare the same flat ITO and the thick LP-CVD $\mathrm{ZnO}$ as front TCO but with random substrates; the LP-CVD ZnO back contact is deposited on glass substrate with feature size of $0.36 \mu \mathrm{m}$ optimised for a-Si:H. The results in this case show that there is an advantage using flat front ITO with 3\% relative increase in $J_{\mathrm{sc}}$. Figure 5 shows that the antireflection effect of the ITO at $550 \mathrm{~nm}$ increases the response compared to the thick $\mathrm{ZnO}$ case, whereas the EQEs in the light trapping region $(600-800 \mathrm{~nm})$ are similar. The IQEs are completely matched and it confirms that the difference between the two TCOs is mostly due to reduced primary reflection losses at the antireflection condition of the ITO $(500-550 \mathrm{~nm})$. In this case (random substrates), no gain is observed due to the roughness or thickness of the front TCO contact.

Thus, the best configuration for a-Si:H solar cell is a random substrate combined with the ITO front contact. Nevertheless, our new combination of periodic substrates and thick LP-CVD $\mathrm{ZnO}$ front contact is almost equivalent with $14.4 \mathrm{~mA} / \mathrm{cm}^{2}$ compared to

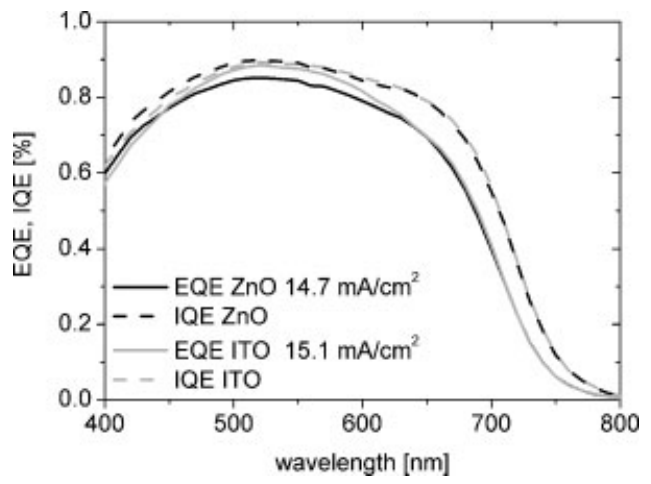

Figure 5. Comparison between flat ITO and rough LP-CVD $\mathrm{ZnO}$ front contacts with a-Si:H solar cells on LP-CVD ZnO substrates
$15 \cdot 1 \mathrm{~mA} / \mathrm{cm}^{2}$ for random substrates combined with ITO front contact.

\section{LP-CVD ZnO and ITO front contacts for thick absorber ( $\mu c-S i: H)$}

This section compares the LP-CVD ZnO and ITO front contacts with thick absorber layer $(>1 \mu \mathrm{m})$. We intend to give results which are valid for $\mu \mathrm{c}-\mathrm{Si}: \mathrm{H}-$ based solar cells where scattering of the light for wavelengths above $700 \mathrm{~nm}$ is needed. This is the case for single cell $\mu \mathrm{c}-\mathrm{Si}: \mathrm{H}$, tandem micromorph or triple junction a-Si:H/ a-Si:H/ $\mu \mathrm{c}-\mathrm{Si}: \mathrm{H}$ cells. In Figure 6, we compare ITO and LP-CVD ZnO layers deposited on top of $1.6 \mu \mathrm{m}$ thick single junction $\mu \mathrm{c}-\mathrm{Si}: \mathrm{H}$ solar cells. The substrate is the 2D periodic grid which provides high $J_{\mathrm{sc}}$ in $\mu \mathrm{c}-\mathrm{Si}: \mathrm{H}$ solar cells and is identical to the one used in Section 'LP-CVD ZnO and ITO Front Contacts for Thin Absorber (a-Si:H)'. Compared to the LP-CVD ZnO front contact, the ITO provides higher $J_{\text {sc }}(4 \%$ relative increase). The antireflection effect of the $70 \mathrm{~nm}$ ITO at $600 \mathrm{~nm}$ increases the spectral response in a wavelength with high photons flux under AM $1.5 \mathrm{~g}$ illumination. In the IR part of the spectrum, the response is equivalent for both TCOs. Remember in Section 'LP-CVD ZnO and ITO Front Contacts for Thin Absorber (a-Si:H)' that for the a-Si:H case, the LP-CVD ZnO front contact improves the EQE. The differences between thick and thin absorber cases are discussed in Section 'Discussion'. The shape of this EQE for LP-CVD $\mathrm{ZnO}$ is linked to interference effects. In the IQE these effects should disappear, but, because the EQE and reflection measurements are performed with two different setups, apparent interferences still remain in the IQE, though

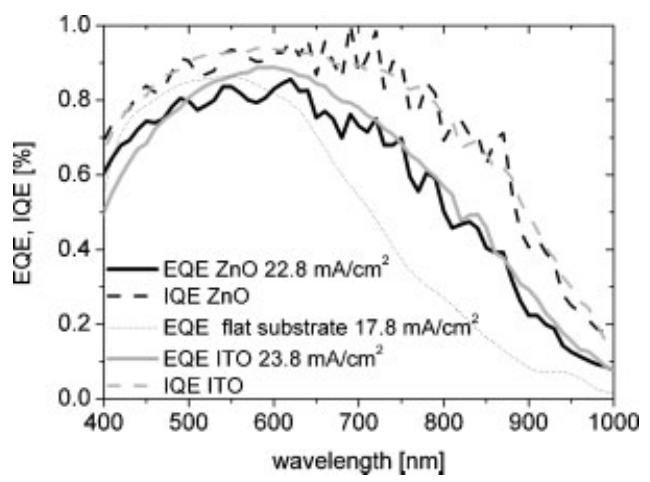

Figure 6. Comparison between flat ITO and rough LP-CVD $\mathrm{ZnO}$ front contacts with $\mu \mathrm{c}-\mathrm{Si}: \mathrm{H}$ solar cells on $2 \mathrm{D}$ periodic grid and flat substrates for reference 
strictly speaking they are artefacts. In Figure 6, a flat substrate with LP-CVD ZnO front contact and thin Ag/ $\mathrm{ZnO}$ back reflector is added for reference. The $J_{\mathrm{sc}}$ gain with the periodic substrate compare to the flat is almost a $30 \%$ relative increase and is in the IR part of the spectrum. Note that the difference between the flat and textured substrates in the blue part of the spectrum (at $400 \mathrm{~nm}$ ) is due to a thinner $\mathrm{p}$ layer thickness on the flat substrate.

We observe the equivalent results for single $\mu \mathrm{c}-\mathrm{Si}: \mathrm{H}$ solar cells deposited on random substrates (LP-CVD $\mathrm{ZnO}$ on glass), i.e. the ITO front contact provide a relative gain of $4 \%$ compare to the LP-CVD $\mathrm{ZnO}$ front contact. The results have been presented in Reference $^{33}$ and here it is also presented in a triple junction a-Si:H/a-Si:H/ $\mu \mathrm{c}-\mathrm{Si}: \mathrm{H}$ solar cell. The TCO comparison results for both single and triple a-Si:H/a-Si:H/ $\mu$ c$\mathrm{Si}: \mathrm{H}$ cells are as expected identical for the total $J_{\mathrm{sc}}$. Note that, different from the a-Si:H case of Section 'LP-CVD $\mathrm{ZnO}$ and ITO Front Contacts for Thin Absorber (a-Si:H)', here for the random substrate (LPCVD $\mathrm{ZnO}$ ) the features of the pyramids have been adapted to the $\mu \mathrm{c}-\mathrm{Si}: \mathrm{H}$ cell; their typical lateral size is now $1 \mu \mathrm{m}$ and the RMS roughness is $140 \mathrm{~nm}$. The structure of the triple junction solar cell is a-Si:H/a$\mathrm{Si}: \mathrm{H} / \mathrm{SOIR} / \mu \mathrm{c}-\mathrm{Si}: \mathrm{H}$ with 80 and $300 \mathrm{~nm}$ for the a-Si:H cells and $1.2 \mu \mathrm{m}$ thick $\mu \mathrm{c}-\mathrm{Si}: \mathrm{H}$ silicon solar cells, respectively. Additionally, the triple cell structure includes $80 \mathrm{~nm}$ thick $\mathrm{SiOx}$ intermediate reflector $(\mathrm{SOIR})^{34}$ between the middle and bottom cells. The lower refractive index of the SOIR $(n=2)$ compared to $\mathrm{Si}(n=4)$ causes reflection of the light in the a-Si:H absorber which increases the $J_{\mathrm{sc}}$ of the top and middle cells. Compared to the rough LP-CVD $\mathrm{ZnO}$ front contact, the ITO provides higher $J_{\mathrm{sc}}$, just as in the single $\mu \mathrm{c}-\mathrm{Si}: \mathrm{H}$ cell case and Figure 7 shows that most of the gain is obtained in the a-Si:H middle cell. The increase in $J_{\mathrm{sc}}$ is around $5 \%\left(5 \cdot 7-6 \cdot 0 \mathrm{~mA} / \mathrm{cm}^{2}\right)$. This effect is important in triple junction cells with two purely a-Si:H cells since the $J_{\mathrm{sc}}$ is limited by the absorption coefficient of the amorphous Si material. Figure 7 illustrates clearly the difficulties of current matching the three solar cells. The a-Si:H cells have $6 \mathrm{~mA} / \mathrm{cm}^{2}$ each and the $\mu \mathrm{c}-\mathrm{Si}: \mathrm{H}$ has $9 \mathrm{~mA} / \mathrm{cm}^{2}$.

So far for thick absorber layers, comparison between the periodic and random substrates is not possible. Indeed, the thickness and crystallinity of the absorber layer are different for $\mu \mathrm{c}-\mathrm{Si}: \mathrm{H}$ absorber of the triple junction solar cell and the single $\mu \mathrm{c}-\mathrm{Si}: \mathrm{H}$ cell. The cells are deposited in two different deposition systems with different plasma conditions. ${ }^{26}$ Hence, we include

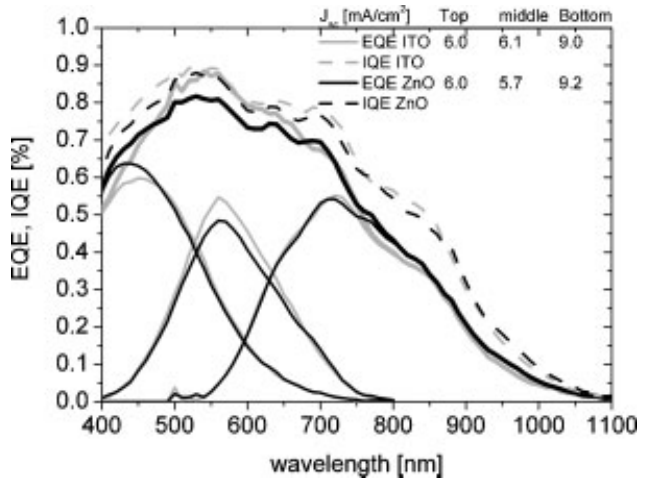

Figure 7. Comparison between flat ITO and rough LP-CVD $\mathrm{ZnO}$ front contacts with triple a-Si:H/a-SiH/ $\mu \mathrm{c}-\mathrm{Si} / \mathrm{H}$ solar cell on a $\mathrm{ZnO}$ LP-CVD substrate

a comparison with a single $\mu \mathrm{c}-\mathrm{Si}: \mathrm{H}$ deposited simultaneously on the periodic and random substrate. Figure 8 shows the EQE comparison of a $1 \cdot 1 \mu \mathrm{m}$ thick $\mu c-S i: H$ cell deposited on the periodic and random substrates. The solar cells have similar $V_{\mathrm{oc}}$ and FF but the $J_{\mathrm{sc}}$ is increased by a relative $6 \%$ to $22.9 \mathrm{~mA} / \mathrm{cm}^{2}$ on the periodic grating compared to the random LP-CVD $\mathrm{ZnO}$. Table I summarises the $J_{\mathrm{sc}}$ of all shown cell structures.

\section{Electrical comparison between ITO and LP-CVD ZnO layers}

The $70 \mathrm{~nm}$ thick ITO has a sheet resistance of $30 \Omega / \square$ and the $2 \mu \mathrm{m}$ thick LP-CVD ZnO has a sheet resistance below $10 \Omega / \square$. At the module level this means that silver fingers or reduction of the width of the solar cell between the interconnection may be necessary for ITO, depending on the $J_{\mathrm{sc}}$ of the cells, as recently showed by

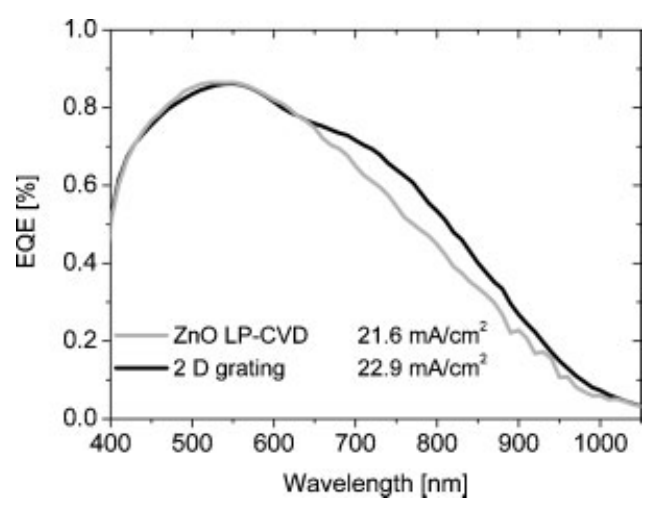

Figure 8. Comparison between random (LP-CVD ZnO) and periodic substrates of single junction $\mu \mathrm{c}-\mathrm{Si}: \mathrm{H}$ solar cell with a LP-CVD $\mathrm{ZnO}$ front contact 
Table I. Summary of $J_{\mathrm{sc}}$ for the a-Si:H and $\mu \mathrm{c}-\mathrm{Si}: \mathrm{H}$ cells deposited on the periodic grating and the random LP-CVD ZnO. The front contact is either thin flat ITO or a thick textured LP-CVD ZnO. The grating and flat substrates are coated with $100 \mathrm{~nm} \mathrm{Ag}$ and $60 \mathrm{~nm} \mathrm{ZnO}$. The $\mathrm{ZnO}$ is LP-CVD ZnO with white paint added at the back of the glass. The $\mu \mathrm{c}-\mathrm{Si}: \mathrm{H}$ solar cell of 1.6 and $1.1 \mu \mathrm{m}$ are deposited in a single chamber and double chamber reactor system, respectively. The $1.6 \mu \mathrm{m}$ single junction $\mu \mathrm{c}-\mathrm{Si}: \mathrm{H}$ and triple junction cells are used to compare the TCOs whereas the $1.1 \mu \mathrm{m}$ cell is used for comparison of random and periodic substrates

\begin{tabular}{|c|c|c|c|c|c|}
\hline $\begin{array}{l}\text { Structure } \\
\text { (Figure 1) }\end{array}$ & $\begin{array}{l}\text { Substrate } \\
\text { texture }\end{array}$ & $\begin{array}{c}\text { Feature size } \\
(\mu \mathrm{m}) / \text { roughness }(\mathrm{nm})\end{array}$ & $\begin{array}{c}\text { Absorber } \\
\text { thickness }(\mu \mathrm{m})\end{array}$ & $\begin{array}{l}\text { Front } \\
\text { TCO }\end{array}$ & $\begin{array}{l}J_{\mathrm{sc}} \text { total } \\
\left(\mathrm{mA} / \mathrm{cm}^{2}\right)\end{array}$ \\
\hline A & Grating & $1 \cdot 2 / 70$ & a-Si:H/0.27 & $\mathrm{ZnO}$ & $14 \cdot 4$ \\
\hline B & Grating & $1 \cdot 2 / 70$ & a-Si:H/0·27 & ITO & $13 \cdot 4$ \\
\hline $\mathrm{C}$ & $\mathrm{ZnO}$ & $0 \cdot 36 / 70$ & a-Si:H/0.27 & $\mathrm{ZnO}$ & $14 \cdot 7$ \\
\hline $\mathrm{D}$ & $\mathrm{ZnO}$ & $0 \cdot 36 / 70$ & a-Si:H/0.27 & ITO & $15 \cdot 1$ \\
\hline Flat & - & - & a-Si:H/0·27 & $\mathrm{ZnO}$ & $12 \cdot 3$ \\
\hline Flat & - & - & $\mathrm{a}-\mathrm{Si}: \mathrm{H} / 0 \cdot 27$ & ITO & $12 \cdot 2$ \\
\hline A & Grating & $1 \cdot 2 / 70$ & $\mu c-S i: H / 1 \cdot 6$ & $\mathrm{ZnO}$ & $22 \cdot 8$ \\
\hline B & Grating & $1 \cdot 2 / 70$ & $\mu c-S i: H / 1 \cdot 6$ & ITO & $23 \cdot 8$ \\
\hline Flat & - & - & $\mu c-S i: H / 1 \cdot 6$ & $\mathrm{ZnO}$ & $17 \cdot 8$ \\
\hline $\mathrm{C}$ & $\mathrm{ZnO}$ & $1 \cdot 0 / 140$ & Triple/1·1 & $\mathrm{ZnO}$ & $20 \cdot 9$ \\
\hline $\mathrm{D}$ & $\mathrm{ZnO}$ & $1 \cdot 0 / 140$ & Triple/1·1 & ITO & $21 \cdot 1$ \\
\hline A & Grating & $1 \cdot 2 / 70$ & $\mu c-\mathrm{Si}: \mathrm{H} / 1 \cdot 1$ & $\mathrm{ZnO}$ & $22 \cdot 9$ \\
\hline $\mathrm{C}$ & $\mathrm{ZnO}$ & $1 \cdot 0 / 140$ & $\mu c-S i: H / 1 \cdot 1$ & $\mathrm{ZnO}$ & $21 \cdot 6$ \\
\hline
\end{tabular}

Brecl and Topic. ${ }^{35}$ In Table II, we report typical electrical parameters for a-Si:H cells and triple junction solar cells with thick $\mathrm{ZnO}$ front contacts and thin ITO front contacts, corresponding to the case of Figure 1C and D, respectively. The effect of the different sheet resistances is not reflected in the FF because the cell area is kept small $\left(0.25 \mathrm{~cm}^{2}\right)$. The difference in FF in the triple junction solar cell is attributed to current mismatch in the three cells. Indeed, the measurement of such a cell is certainly a difficult issue because of the current matching of the three cells, and hence the FF is strongly sensitive to deviations of the solar simulator spectrum from the AM $1.5 \mathrm{~g}$ spectrum. Furthermore, a $V_{\mathrm{oc}}$ reduction between 20 and $30 \mathrm{mV}$ is observed for the flat ITO for both single and triple junction solar cells. This is attributed to the non-optimised $\mathrm{p} / \mathrm{ITO}$ interface which needs further optimisation as reported elsewhere. ${ }^{36}$ In addition, we also cannot exclude that during the deposition of ITO, the sputtering could damage the thin $\mathrm{p}$ layer.

\section{DISCUSSION}

\section{Gratings and conformity of the deposited layers}

Figure 9 shows a SEM micrograph of a $\mu \mathrm{c}-\mathrm{Si}: \mathrm{H}$ solar cell cross-section prepared by focused ion beam (FIB). The cell has an absorber layer thickness of $1 \mu \mathrm{m}$ on the $2 \mathrm{D}$ periodic grating. The back contact structure consists of a double layer of $80 \mathrm{~nm}$ of silver plus $70 \mathrm{~nm}$ of $\mathrm{ZnO}$. Such thin layers guarantee an elevated degree of conformality at each interface, and they closely reproduce the grating characteristics. However, considerable flattening of the structure is observed throughout the $1 \mu \mathrm{m}$ thick $\mu \mathrm{c}-\mathrm{Si}: \mathrm{H}$ layer. Finally, after the deposition of $3 \mu \mathrm{m}$ of LP-CVD ZnO, the shape of the grating has completely disappeared,

Table II. Solar cell parameters of a-Si:H and triple a-Si/a-Si/ $\mu \mathrm{c}-\mathrm{Si}: \mathrm{H}$ junction solar cells with thin ITO and thick LP-CVD $\mathrm{ZnO}$ front contact. The substrates are LP-CVD $\mathrm{ZnO}$ on glass with the feature size adapted for a-Si:H $(360 \mathrm{~nm})$ and $\mu \mathrm{c}-\mathrm{Si}: \mathrm{H}(1 \mu \mathrm{m})$

\begin{tabular}{lccccc}
\hline & $V_{\mathrm{oc}}(\mathrm{mV})$ & FF $(\%)$ & $J_{\text {sc }}\left(\mathrm{mA} / \mathrm{cm}^{2}\right)$ & \multicolumn{2}{c}{ Efficiency $(\%)$} \\
\hline ZnO single a-Si:H & 864 & 66 & $14 \cdot 7$ & $8 \cdot 4$ & Figure 1C \\
ITO single a-Si:H & 835 & 66 & $15 \cdot 1$ & $8 \cdot 3$ & Figure 1D \\
ITO triple & 2126 & 67 & $6 \cdot 0$ & $8 \cdot 5$ & Figure 1D \\
ZnO triple & 2157 & 64 & $5 \cdot 7$ & $7 \cdot 9$ & Figure 1C \\
\hline
\end{tabular}




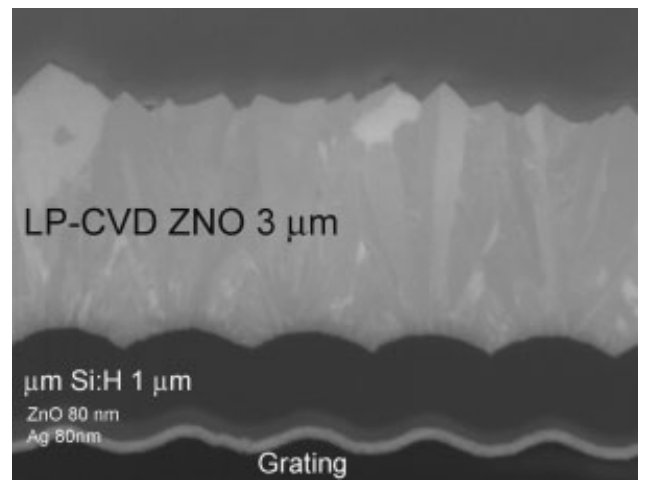

Figure 9. SEM micrograph of a $\mu \mathrm{c}-\mathrm{Si}$ solar cell with a front $\mathrm{ZnO} \mathrm{LP}-\mathrm{CVD}$ front contact deposited on the 2D crossgratings

and is now replaced by the intrinsic texture of the LPCVD $\mathrm{ZnO}$.

We consider two effects to tentatively explain the observed behaviour of the solar cells deposited on the grating. First, the effectiveness of light scattering at the diffractive grating structures is seriously influenced by the changes of the interface morphology. Indeed, we distinguish the case of thin layers $(<500 \mathrm{~nm})$ which reproduce the initial surface morphology at both the back and the front interface of the absorber layer and the case of thick absorber layers $(>1 \mu \mathrm{m})$ which flatten the surface texture of the substrate. For a description of the diffraction at the periodically structured interfaces we have to keep in mind that diffraction is a far field phenomenon. Thus, we make use of the well-known grating equation for assessing the light propagation in those layers where the layer thickness exceeds the effective wavelength $\lambda_{\text {eff }}=\lambda_{0} / n$ ( $\lambda_{0}$ : wavelength in vacuum, $n$ : refractive index):

$$
\begin{gathered}
n_{1} \sin \left(\theta_{1}\right)-n_{2} \sin \left(\theta_{2}\right)=\frac{m \lambda_{0}}{D}, \\
m=0, \pm 1, \pm 2, \pm 3, \ldots
\end{gathered}
$$

Here, $\theta_{1,2}$ denote the incident and diffractive angles. The wavelength and periodicity of the grating are denoted by $\lambda_{0}$ and $D$, respectively, and the diffraction order is given by the integer $m$. For solar cell applications, it is important to know the diffracted intensities into each order. For the case of a sinusoidal grating an exact solution exists which predicts that the intensity diffracted into the $m$ th order is proportional to the square of the $m$ th Bessel function, where the argument of the Bessel function contains the wave- length and the grating amplitude. ${ }^{19}$ In its most simple form, the validity of this prediction is only valid for small diffracted angles, whereas we are mostly interested in elevated diffracted angles in our device. An extended range of validity was reported with a 'non-paraxial correction' where the intensity of a particular mode is normalised by the sum over the intensities of all propagating modes as proposed by Harvey and Krymonos. ${ }^{37}$

A second observation addresses the condition of total internal reflection (TIR) for the case of flat interfaces, transmission into a medium with lower refractive index is prohibited when the incident angle exceeds the Brewster angle because the angle of the refracted beam would exceed $90^{\circ}$. However, when the surface is periodically textured, diffraction may occur into angles below $90^{\circ}$, and these orders are still allowed to propagate. Thus, a grating at the front interface can relax the condition of TIR by introducing escape modes for the light!

\section{Thick absorber ( $\mu c$-Si:H)}

Our results show the optical advantage of flat thin ITO front contacts compared to the rough thick LP-CVD $\mathrm{ZnO}$ for single and multijunction structures which have thick absorber layers (above $1 \mu \mathrm{m}$ ). Indeed, the antireflection of the ITO is ideal with no reflected light from the solar cell at $550 \mathrm{~nm}$. First, the thick layer (between 1 and $3 \mu \mathrm{m}$ ) of microcrystalline material flattens the interface $\mathrm{TCO} / \mathrm{Si}$ and thus also the interface air/TCO as discussed in Section 'Gratings and Conformity of the Deposited Layers'. In this case the light would see a flat or flattened interface at the front of the solar cell and light trapping would be achieved by diffraction at the back reflector, as shown in the case B of Figure 10. Note that even if the interface is not completely flat, the depth of the grating is decreased, and according to the grating theory this leads to decreased diffraction intensities. If we consider, for multijunction structures, that the wavelength of interest for light trapping is typically about $900 \mathrm{~nm}$, we can compute the diffraction angles and intensities at the $\mathrm{Si} / \mathrm{ZnO} / \mathrm{Ag}$ interface of the back reflector using Equation (1), the "non-paraxial correction' and perpendicular incidence $\left(\theta_{1}=0\right)$. In fact, this grating is well suited for this optical situation because our calculation shows that $65 \%$ of the light is reflected at the silicon/ $\mathrm{ZnO} / \mathrm{Ag}$ with angles higher than $16^{\circ}$. Note that, $16^{\circ}$ is the angle of internal reflection at the front $\mathrm{Si} / \mathrm{TCO} /$ air interface if we consider this interface 

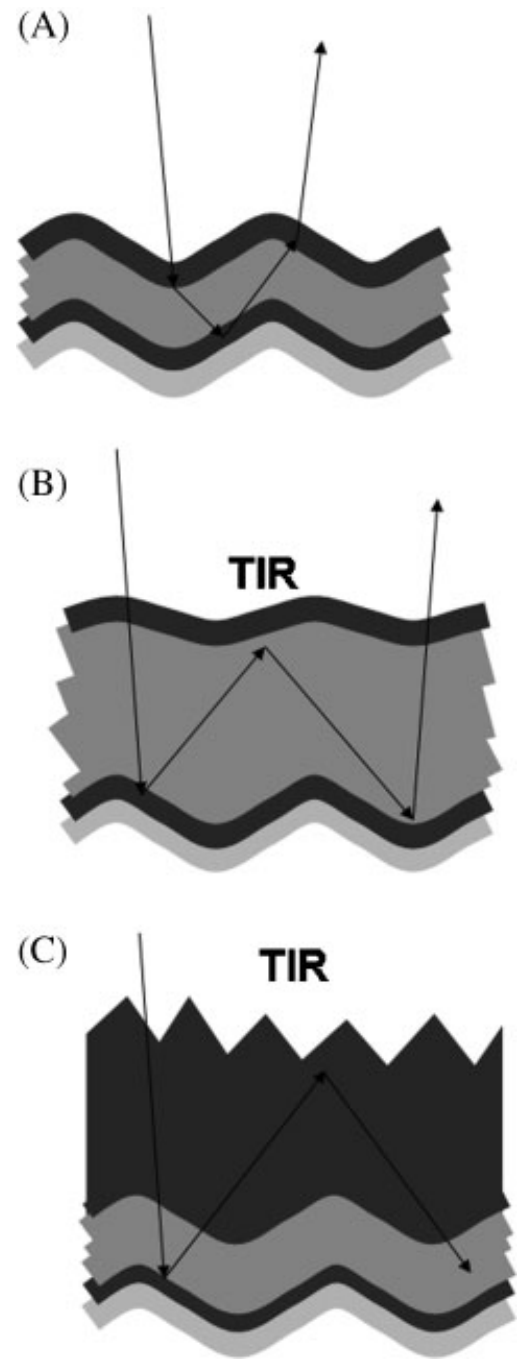

Figure 10. Schematic illustration of the light path in thin (A) and thick (B) absorber layers. A grating on the front surface allows out-coupling of light even at angles above the angle of total internal reflection. When the front interface is flattened due to the growth of a thicker absorber layer, the condition of total internal reflection is more and more restored, allowing two more passes through the structure (B). Note that the antireflection condition of the ITO layer is also valid for the light that is coupled out of the device. When the periodicity at the front interface is lost due to the growth of a thicker TCO layer, the condition of total internal reflection is partly restored at the $\mathrm{TCO} /$ air interface, allowing more passes through the structure $(\mathrm{C})$

as flat, further assuming refractive indexes of 4 for silicon, 2 for the TCOs (ITO or $\mathrm{ZnO}$ ), and 1 for air. Note that the angle of TIR of the $\mathrm{Si} / \mathrm{TCO} /$ air system is equal to the TIR of the Si/air system, independent from the refractive index of the TCO. This situation corresponds to our experimental results. Indeed, this substrate achieves large increases in $J_{\mathrm{sc}}$ in the IR part of the spectrum compare to the flat substrate as shown in Section 'LP-CVD ZnO and ITO Front Contacts for Thick Absorber ( $\mu \mathrm{c}-\mathrm{Si}: \mathrm{H})$ ' and Figure 6 . We think that in our structure, the flattening of the front $\mathrm{Si} / \mathrm{TCO}$ interface will result in an increase in reflection at the first $\mathrm{Si} / \mathrm{TCO}$ interface. Hence, a thin ITO becomes extremely important to reduce the reflection at this interface and enhance the in-coupling of the light in the thick absorber layer. In addition, we see that the rough $\mathrm{ZnO} /$ air interface does not add any extra light trapping in the device. We think that scattering occurs at the front interface (air/ZnO) but the moderate scattering power of the LP-CVD $\mathrm{ZnO}$ in air for IR wavelengths does not contribute significantly to this light trapping scheme of the solar cells.

\section{Thin absorber (a-Si:H)}

The solar cell results show that in the case of a thin absorber layer the optical properties change. We suppose that here the grating properties are reproduced at each interface of the a-Si:H solar cell. Our considerations focus on the behaviour of a light wave with a wavelength of $700 \mathrm{~nm}$ which is in the light trapping region of the a-Si:H solar cells. We assume that two diffractions take place in the device, one at the front TCO/Si interface of the solar cell and one at the back reflector of the solar cell. Using these approximations and perpendicular irradiation $\left(\theta_{1}=0\right)$, the result of the diffraction equation (1) for the front $\mathrm{TCO} /$ Si interface gives six orders of diffractions with $57 \%$ of the intensity having angles higher than $50^{\circ}$. Thus, the situation is almost ideal for our device with large diffraction angles. However, our experimental results with an ITO front contact shows that the light trapping is far from optimal. We think that the poor performance of the thin a-Si:H cell with the flat ITO on the 2D grating is explained by a different interaction between the escaping light (after the diffraction by the back contact) and the Si/ITO/air interface. Indeed, the grating properties will tend to relax the internal reflection, and out-coupling of the light from the device becomes possible. Additionally, the thin ITO layer acts as an antireflection layer in this direction which reinforces the out-coupling of light. However, when the thick LP-CVD $\mathrm{ZnO}$ front contact is used, the out-coupling of the light at the $\mathrm{ZnO} / \mathrm{Si}$ interface takes place but the grating properties are lost at the $\mathrm{ZnO}$ /air interface. Hence, internal reflection at the $\mathrm{ZnO} / \mathrm{air}$ 


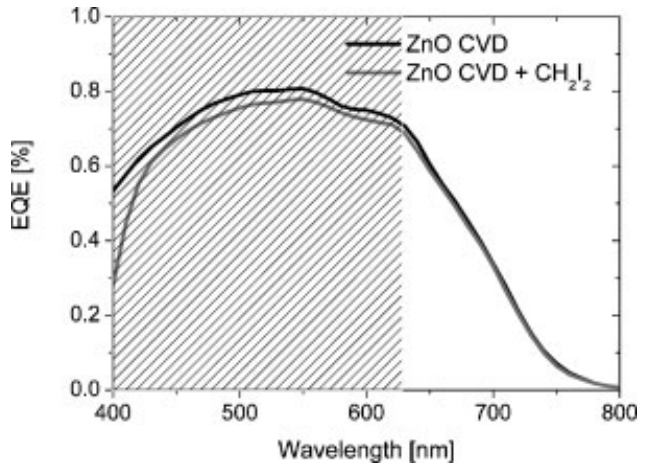

Figure 11. Comparison of a-Si:H EQE with ZnO LP-CVD front contacts and with a drop of $\mathrm{CH}_{2} \mathrm{I}_{2}$ on top of the $\mathrm{ZnO} \mathrm{LP}-$ CVD

interface is restored (at least partly). Thus, the light trapping is enhanced as described in Figure 10.

In order to make sure that it was not the roughness of the LP-CVD $\mathrm{ZnO}$ which enhances the scattering of the light in our device, we 'switched off' the roughness by applying an optically thick film of index matching $\mathrm{CH}_{2} \mathrm{I}_{2}$. Figure 11 compares EQEs of a-Si:H cell with a rough LP-CVD ZnO surface and the same cell measured through the index matching fluid which yields a flat surface. Note that $\mathrm{CH}_{2} \mathrm{I}_{2}$ absorbs below $450 \mathrm{~nm}$, but in the light trapping region between 650 and $800 \mathrm{~nm}$ the EQEs are essentially unchanged. This confirms that the roughness of the front surface does not play a significant role in the light trapping of this device. This is in accordance with Figure 3 which shows that the Haze of the $\mathrm{ZnO}$ LP-CVD for wavelength above $700 \mathrm{~nm}$ is relatively low, i.e. below $25 \%$. However at shorter wavelength, we still expect advantages in the textured front surface because of reduced primary reflection at the TCO/air interface. Indeed, the substrate roughness provides an index grading with the air which diminishes primary reflection.

In the case of random substrate (LP-CVD ZnO), the sharp and random morphology provides rough interfaces at both the back and the front of the cell, which efficiently scatters light into the absorber by the multiple scattering of the light at every interface of the device, and no dominant diffraction occurs. Here, the antireflection effect of a flat thin ITO is a better choice, because of the higher $J_{\mathrm{sc}}$ in the solar cells. This effect would even be reinforced after encapsulation thanks to the enhanced index matching in the three layer system air/encapsulant/ITO.

\section{Light trapping and device performances}

The light trapping properties in a-Si:H nip solar cells on a variety of substrate structures have previously been reported by Daudrix et al. ${ }^{38}$ Using textured LPCVD ZnO front contacts, the authors reported current enhancements up to $16 \%$ with respect to cells on flat substrates. Summarising our results on light trapping in a-Si:H Section 'LP-CVD $\mathrm{ZnO}$ and ITO Front Contacts for Thin Absorber (a-Si:H)', we find current enhancements between 8 and $18 \%$, depending on the combination of back contact texture and the choice of front contact. The performance of periodic and randomly textured substrates is comparable when a rough $\mathrm{ZnO}$ front contact is used. However, on randomly textured substrates, a superior performance is observed for a thin ITO front contact because of the additional antireflection effect between ITO and $\mathrm{Si}$.

For $\mu \mathrm{c}-\mathrm{Si}: \mathrm{H}$ solar cells Haase and Stiebig performed an analysis of the light trapping properties by numerically solving Maxwell's equations. ${ }^{39}$ For a substrate consisting of an array of regular pyramids they predict $J_{\mathrm{sc}}$ of $21 \mathrm{~mA} / \mathrm{cm}^{2}$ for $1 \mu \mathrm{m}$ thick absorber layers. Heine and Morf $^{23}$ suggest blazed gratings as ideal substrate because the reduced symmetry of the system prevents out-coupling into a zero order beam. In Section 'LP-CVD ZnO and ITO Front Contacts for Thick Absorber ( $\mu \mathrm{c}-\mathrm{Si}: \mathrm{H})$ ', we studied the performance of $\mu \mathrm{c}-\mathrm{Si}: \mathrm{H}$ solar cells on a simple sinusoidal grating. In cells with a $1.1 \mu \mathrm{m}$ thick absorber layer, we find $J_{\mathrm{sc}}$ of $22.9 \mathrm{~mA} / \mathrm{cm}^{2}$ with an important advantage compared to random substrates. This $J_{\mathrm{sc}}$ compares well to state-of-the-art $\mu \mathrm{c}-\mathrm{Si}: \mathrm{H}$ devices on random structures for equivalent thicknesses. ${ }^{28,40}$ We think that more refined grating structures, e.g. the implementation of blazing still leaves some room for improvements on periodic substrates.

Our investigations show that ITO represents a favourable choice of TCO for nip cells with thick absorber structures like micromorph tandem or triple junction solar cells. In fact, ITO is used as a front contact by several companies. ${ }^{40,41}$ Specifically for triple cells, $V_{\mathrm{oc}}$ and sheet resistance are less of a concern because the voltage of the cell is higher (over $2 \mathrm{~V}$ ) and the current density is relatively low $\left(6 \mathrm{~mA} / \mathrm{cm}^{2}\right.$, see Table I). The triple junction solar cell with $\mu \mathrm{c}-\mathrm{Si}: \mathrm{H}$ bottom cell and pure a-Si:H top and middle cells is fully compatible with production constraint because only a relatively thin $\mu c-S i: H$ layer $(<1 \mu \mathrm{m})$ is required. In contrast, 
a matched $J_{\mathrm{sc}}$ of 12 or $13 \mathrm{~mA} / \mathrm{cm}^{2}$ in a micromorph device requires a thicker absorber which necessitates a high deposition rate of the $\mu \mathrm{c}-\mathrm{Si}: \mathrm{H}$ material. $^{12,41}$

\section{CONCLUSION}

Our study reveals that the interaction between the front and back surface structures is not trivial to understand. It gives clear guidelines for substrate and TCO optimisation taking into account different substrate textures and absorber thicknesses. For thick absorbers it is essential to provide a suitably scattering back contact because loss of conformity due to the thick layer reduces the scattering properties of the front interfaces. We have demonstrated that on textured substrate, a textured front TCO does not enhance the $J_{\mathrm{sc}}$ by additional scattering of the light in the front interface compared to flat ITO. Hence, ITO is a better choice for the front contact thanks to the efficient antireflection effect between air and silicon. In addition, the AR can be tuned to be specially favourable in the green region which is adapted for triple junction solar cells. For thin absorbers, the thick textured $\mathrm{ZnO}$ front contact is almost equivalent to the ITO front contact on random substrates and can be advantageous in combination with periodic substrate structure because it switches off the periodicity of the grating at the front interface. Indeed, on the periodic substrate, we achieve $J_{\mathrm{sc}}$ of $14.4 \mathrm{~mA} / \mathrm{cm}^{2}$ with a $\mathrm{ZnO}$ front contact, which is a $7 \%$ relative increase compare to the standard ITO front contact.

\section{Acknowledgements}

This work was performed within the EU-Project 'Flexcellence' under contract 019948 and with funding from the Swiss Federal Energy Office (OFEN) under contract 153032. We thank J. Steinhauser for the $\mathrm{ZnO}$ optical measurements and M. Leboeuf for SEM investigation.

\section{REFERENCES}

1. Chittick RC, Alexander JH, Sterling HF. The preparation and properties of amorphous silicon. Journal of The Electrochemical Society 1969; 116: 77.

2. Jäger-Waldau A. PV STATUS 2007. Office for Official Publications of the European Communities 2007.
3. Banerjee A, Guha S. Study of back reflectors for amorphous silicon alloy solar cell application. Journal of Applied Physics 1991; 69: 1030-1035.

4. Bailat J, Terrazzoni-Daudrix V, Guillet J, Freitas F, Niquille X, Shah A, Ballif C, Scharf T, Morf R, Hansen A, Fischer D, Ziegler Y, Closset A. Recent development of solar cells on low-cost plastic substrates. Proceedings of the 20th European PVSEC 2005; 1529-1532.

5. Meier J, Dubail S, Golay S, Kroll U, Fay S, VallatSauvain E, Feitknecht L, Dubail J, Shah A. Microcrystalline silicon and the impact on micromorph tandem solar cells. Solar Energy Materials and Solar Cells 2002; 74: 457-467.

6. Haug F-J, Söderström T, Niquille X, Ballif C. Development of micromorph tandem solar cells on low cost plastic substrates. Accepted in Solar Energy Material 2008.

7. Staebler DL, Wronski CR. Reversible conductivity changes in discharge-produced amorphous Si. Applied Physics Letters 1977; 31: 292-294.

8. Meier J, Spitznagel J, Faÿ S, Bucher C, Graf U, Kroll U, Dubail S, Shah A. Enhanced light trapping for micromorph tandem solar cells by LP-CVD. Proceedings of the 29th IEEE PVSC 2002; 1118.

9. Eisele C, Nebel CE, Stutzmann M. Periodic light coupler gratings in amorphous thin film solar cells. Journal of Applied Physics 2001; 89: 7722.

10. Yamamoto K, Yoshimi M, Suzuki T, Nakata T, Sawada T, Nakajima A, Hayashi K. Large area and high efficiency a-Si/poly-Si stacked solar cell submodule. Proceedings of the 28th IEEE PVSEC 2000; 1428-1432.

11. Kluth O, Rech B, Houben L, Wieder S, Schöpe G, Beneking C, Wagner H, Löffl A, Schock HW. Texture etched $\mathrm{ZnO}: \mathrm{Al}$ coated glass substrates for silicon based thin film solar cells. Thin Solid Films 1999; 351: 247253.

12. Mai Y, Klein S, Carius R, Wolff J, Lambertz A, Finger F, Geng X. Microcrystalline silicon solar cells deposited at high rates. Journal of Applied Physics 2005; 97: 114913.

13. Meier J, Spitznagel J, Kroll U, Bucher C, Fay S, Moriarty T, Shah A. High-efficiency amorphous and "micromorph" silicon solar cells. Proceedings of the 3rd world WCPEC 2003; 3: 2801-2805.

14. Dominé D, Bailat J, Steinhauser J, Shah A, Ballif C. Micromorph solar cell optimization using a $\mathrm{ZnO}$ layer as intermediate reflector. Proceedings of the 4th world WCPEC 2006; 1465-1468.

15. Dominé D, Buehlmann P, Bailat J, Billet A, Feltrin A, Ballif C. Optical management in high-efficiency thinfilm silicon micromorph solar cells with a silicon oxide based intermediate reflector. Physica Status Solidi (RRL) Rapid Research Letters 2008; 2: 163-165.

16. Yang X, Yan B, Yue G, Jiang C-S, Owens J, Yang J, Guha S. Optical enhancement by textured back reflector in 
amorphous and nanocrystalline silicon based solar cells. Mater. Res. Soc. Symp. Proc. 2008; 1101E: KK13.2.

17. Springer J, Poruba A, Mullerova L, Vanecek M, Kluth O, Rech B. Absorption loss at nanorough silver back reflector of thin-film silicon solar cells. Journal of Applied Physics 2004; 95: 1427-1429.

18. Haug FJ, Söderström T, Cubero O, Terrazzoni-Daudrix $\mathrm{V}$, Ballif C. Plasmonic absorption in textured silver back reflectors of thin film solar cells. Journal of Applied Physics 2008; 104: 064509.

19. Beckman P, Spizzichno A. The Scattering of Electromagnetic Wave from Rough Surfaces. Pergamon Press: Oxford, 1963; Chapter 5.

20. Krc J, Smole F, Topic M. Analysis of light scattering in amorphous Si:H solar cells by a one-dimensional semicoherent optical model. Progress in Photovoltaics: Research and Applications 2003; 11: 15-26.

21. Zeman M, Willemen JA, Tao G, Metselaar JW. Computer modelling of a-Si: $\mathrm{H}$ based solar cells. Applied Solar Energy 1995; 31: 30-41.

22. Springer J, Poruba A, Vanecek M, Fay S, Feitknecht L, Wyrsch N, Meier J, Shah A, Repmann T, Kluth O. Improved optical model for thin film silicon solar cells. Proceedings of the 17th PVSEC 2001; 2830-2835.

23. Heine C, Morf RH. Submicrometer gratings for solar energy applications. Applied Optics 1995; 34: 2476-2482.

24. Stiebig H, Haase C, Zahren C, Rech B, Senoussaoui N. Thin-film silicon solar cells with grating couplers-An experimental and numerical study. Journal of NonCrystalline Solids 2006; 352: 1949-1952.

25. Haase C, Stiebig H. Optical properties of thin-film silicon solar cells with grating couplers. Progress in Photovoltaics: Research and Applications 2006; 14: 629-641.

26. Haug F-J, Terrazzoni-Daudrix V, Söderström T, Niquille $\mathrm{X}$, Bailat J, Ballif C. Flexible microcrystalline silicon solar cells on periodically textured plastic substrates. Proceedings of the 21st European PVSEC 2006; 1651.

27. Soderstrom T, Haug FJ, Terrazzoni-Daudrix V, Ballif C. Optimization of amorphous silicon thin film solar cells for flexible photovoltaics. Journal of Applied Physics 2008; 103: 114509-8.

28. Bailat J, Domine D, Schluchter R, Steinhauser J, Fay S, Freitas F, Bucher C, Feitknecht L, Niquille X, Tscharner T, Shah A, Ballif C. High-efficiency p-i-n microcrystalline and micromorph thin film silicon solar cells deposited on LPCVD $\mathrm{ZnO}$ coated glass substrates. Proceedings of the 4th World WCPEC 2006; 4.

29. Python M, Vallat-Sauvain E, Bailat J, Dominé D, Fesquet L, Shah A, Ballif C. Relation between substrate surface morphology and microcrystalline silicon solar cell performance. Journal of Non-Crystalline Solids 2008; 354: 2258-2262.
30. Soderstrom T, Haug F-J, Terrazzoni-Daudrix V, Niquille X, Ballif C. N/I Buffer layer for substrate microcrystalline thin film silicon solar cells. Accepted in Journal of Applied Physics 2008; 104.

31. Fay S, Kroll U, Bucher C, Vallat-Sauvain E, Shah A. Low pressure chemical vapour deposition of $\mathrm{ZnO}$ layers for thin-film solar cells: temperature-induced morphological changes. Solar Energy Materials and Solar Cells 2005; 86: 385-397.

32. Steinhauser J, Feitknecht L, Faÿ S, Schlüchter R, Shah A, Ballif C, Springer J, Mullerova-Hodakova L, Purkrt A, Poruba A, Vanecek M. Effect of rough zno layers in improving performances of microcrystalline silicon solar cell. Proceedings of the 20th European PVSEC 2005; 1608-1611.

33. Söderström T, Haug F-J, Cubero O, Niquille X, Ballif C. Optical developments for silicon thin film solar cells in the substrate configuration. Proc. of the Mater. Res. Soc. Symp. 2008; 1101E: KK04-05.

34. Buehlmann P, Bailat J, Domine D, Billet A, Meillaud F, Feltrin A, Ballif C. In situ silicon oxide based intermediate reflector for thin-film silicon micromorph solar cells. Applied Physics Letters 2007; 91: 143505.

35. Brecl K, Topic M. Simulation of losses in thin-film silicon modules for different configurations and front contacts. Progress in Photovoltaics: Research and Applications 2008; 16: 479-488.

36. Li H, Stolk RL, van der Werf CHM, Franken RH, Rath JK, Schropp REI. Optimization of $n-i-p$ protocrystalline SiGe: $\mathrm{H}$ thin film solar cells for application in thin film multijunction solar cells. Journal of Non-Crystalline Solids 2006; 352: 1941-1944.

37. Harvey JE, Krywonos A. A global view of diffraction: revisited. In Proc. SPIE, Denver 2004; AM100: 26.

38. Daudrix VT, Guillet J, Freitas F, Shah A, Ballif C, Winkler P, Ferreloc M, Benagli S, Niquille X, Fischer D. Characterisation of rough reflecting substrates incorporated into thin-film silicon solar cells. Progress in Photovoltaics: Research and Applications 2006; 14: 485.

39. Haase C, Stiebig H. Thin-film silicon solar cells with efficient periodic light trapping texture. Applied Physics Letters 2007; 91: 061116.

40. Yamamoto K, Yoshimi M, Tawada Y, Okamoto Y, Nakajima A, Igari S. Thin-film poly-Si solar cells on glass substrate fabricated at low temperature. Applied Physics A: Materials Science \& Processing 1999; 69: 179-185.

41. Saito K, Sano M, Otoshi H, Sakai A, Okabe S, Ogawa K. High efficiency large area solar cells using microcrystalline silicon. Proceedings of the 3rd World WCPEC 2003; S2O-B9-04. 